\title{
Bond strength of glass fiber posts submitted to different luting protocols
}

Fabiano Vieira de Landa ${ }^{a}$, Jean Soares Miranda ${ }^{a}$, Rodrigo Furtado de Carvalho ${ }^{a}$, Estevão Tomomitsu Kimparab ${ }^{\mathrm{b}}$, Fabíola Pessôa Pereira Leite ${ }^{\mathrm{a}}$

\begin{abstract}
Objective: evaluate the effect of different luting protocols on the bond strength of glass fiber posts. Methods: Forty human canine teeth were randomly divided into four groups: Relyx U100/Endofill $(R+E)$, Panavia F2.0/EndoFill (P+E), Relyx U100/Sealer $26(R+S)$, Panavia F2.0/Sealer $26(P+S)$. After the luting procedures, the samples were subjected to thermocycling $\left(6.000\right.$ cycles; at $5 \pm 1^{\circ} \mathrm{C}$ and $55 \pm 1^{\circ} \mathrm{C}$ ) and then sectioned in a precision cutting machine (Isomet 1000 Precision Saw) into 4 cuts of $2 \mathrm{~mm}$ regarding to different deepness: Apical, Medium Apical, Medium Coronal, and Coronal. Next, the cuts were submitted to push-out test in a universal testing machine (EMIC) with load cell of $50 \mathrm{~N}$, at crosshead speed of $0.5 \mathrm{~mm} / \mathrm{min}$.

Results: They were obtained according to the different luting deepness $(p \geq 0.05)(\mathrm{MPa})$ : 1) apical $-R+E(1.35 \pm 1.28), P+E(2.70 \pm 0.89), R+S(3.89 \pm 0.70), P+S(4.30 \pm 1.02) ; 2)$ medium apical $-R+E(1.38 \pm 1.28), P+E(2.98 \pm 1.43), R+S(4.02 \pm 1.14), P+S(4.49 \pm 1.82) ; 3)$ medium coronal $-R+E(2.46 \pm 0.73), P+E(3.72 \pm 0.78), R+S(4.85 \pm 0.71), P+S(6.14 \pm 0.73) ; 4)$ coronal $R+E(5.59 \pm 1.08), P+E(5.74 \pm 1.06), R+S(6.71 \pm 1.07), P+S(7.40 \pm 1.51)$

Conclusion: There was a relationship between the luting protocol of the glass fiber post and the endodontic cement. Eugenol plays an important role inside the dentinal tubules by interfering negatively in the bond strength to root dentin.
\end{abstract}

Key words: Glass fiber post; Endodontic cement; Adhesion

\section{Resistência de união de pinos de fibra de vidro submetidos a diferentes protocolos de cimentação}

\section{RESUMO}

Objetivo: Avaliar o efeito de diferentes protocolos de cimentação na resistência de união de pinos de fibra de vidro.

Metodologia: Foram utilizados 40 caninos humanos, os quais foram divididos aleatoriamente em quatro grupos. R+E Relyx U100/ Endofill, P+E Panavia F2.0/EndoFill, R+S Relyx U100/Sealer 26, P+S Panavia F2.0/Sealer 26. Ao término dos procedimentos de cimentação, os corpos de prova foram seccionados em uma máquina de corte de precisão (Lab Cut Isomet 1000 Precision Saw) em 4 fatias de $2 \mathrm{~mm}$ referente as diferentes profundidades: Apical, Médio Apical, Médio Coronal, Coronal. Em seguida, as fatias foram submetidas a ensaios mecânicos de extrusão Push-out em uma máquina de ensaios mecânicos EMIC com célula de carga de $50 \mathrm{~N}$, a velocidade de $0,5 \mathrm{~mm} / \mathrm{min}$.

Resultados: 1) Porção apical $R+E(1,35+1,28), P+E(2,70+0,89), R+S(3,89+0,70), P+S(4,30 \pm 1,02)$ : 2) porção médio apical $R+E(1,38 \pm 1,28), P+E(2,98 \pm 1,43), R+S(4,02 \pm 1,14), P+S(4,49 \pm 1,82) ; 3)$ porção médio coronal $R+E(2,46 \pm 0,73), P+E(3,72 \pm 0,78), R+S(4,85 \pm 0,71), P+S(6,14 \pm 0,73) ; 4)$ porção coronal $R+E(5,59 \pm 1,08), P+E(5,74 \pm 1,06), R+S(6,71 \pm 1,07), P+S(7,40 \pm 1,51)$

Conclusão: Houve uma relação entre o protocolo de cimentação do pino de fibra de vidro e de cimento endodôntico. Eugenol desempenha um papel importante no interior dos túbulos dentinários, interferindo negativamente na resistência de união à dentina radicular.

Palavras-chave: Pino de fibra de vidro; Cimento endodôntico; Adesão a Faculdade de Odontologia da Universidade Federal de Juiz de Fora, Juiz de Fora, Minas Gerais Brazil

${ }^{\mathrm{b}}$ Instituto de Ciência e Tecnologia - UNESP de São José dos Campos, São Paulo, Brazil

Conflict of Interests: The authors state that there re no financial and personal conflicts of interest that could have inappropriately influenced their work.

Copyright: (c) 2016 de Landa et al.; licensee EDIPUCRS. 


\section{INTRODUCTION}

The main goal of an intraradicular post is to provide adequate retention for the core material when a reduced crown remnant is present. Glass fiber posts associated with resin composites have been a clinical option chosen by dentists because of its easiness and low cost, providing a fast and effective clinical result with biomechanical benefits to tooth remnant $[1,2]$.

The adhesive luting of glass fiber posts is a sensitive procedure since technical problems can begin from the removal of the canal obturation to the luting procedure itself. Among the main problems found, it can be cited: control of humidity, acid etching procedure, amount and evaporation of the adhesive agent, and light intensity at the most apical portions of root canals. These problems may influence significantly on the physical and biological properties of the restorations [3].

The choice for the adhesive system can also directly affect the retention of glass fiber posts. The use of adhesive systems promotes an effective bonding of the resin luting agent to root dentin, which is a relevant factor for adhesive longevity [4]. Prefabricated posts show an interaction with the adhesive systems therefore resulting in higher retention, easier luting procedure, and simpler technique $[5,6,7]$.

The composition of the endodontic cement may also affect the bonding of the resin luting agent to root dentin. The effect of endodontic cements on the retention of intraradicular posts has pointed out to a decrease of the bond strength of resin luting agents to root canals filled with eugenol-based materials [5]. Eugenol interferes in the polymerization of resin compounds because it alters their mechanical and physical properties due to its contact to the root walls and penetration within dentinal tubules thus affecting the retention of glass fiber posts $[8,9,10]$.
The polymerization procedure is of great importance because the resin compounds should be activated to achieve the conversion of monomers into polymeric chains consequently reaching the material's polymerization, so that the ranging in the levels of polymerization significantly influences the bonding of the resin luting agents to root dentin [4]. To compensate for this limitation, self-cured resin cements have been developed, in which the polymerization process is initiated by photoactivation and complemented by the action of self-curing catalyzers within its composition, consequently associating the advantages of photo- and selfcured luting agents [11].

A self-adhesive resin cement was developed aiming to improve some of the unfavorable characteristics, from a clinical point of view, of the cements currently available (zinc phosphate, glass ionomer, resin modified glass ionomer, and resin cements). This luting agent does not require any previous treatment of tooth substrate. The steps of acid etching, primer and bonding agent application are eliminated. After its mixing, the luting procedure is simplified and its application is a single clinical step [4,5].

Considering that root canals are an adverse scenario for the use of resin materials, the controversies in relation to the mechanical behavior of resin cements during the cementation of glass fiber posts and the influence of the endodontic cement composition on the bond strength of root dentin to glass fiber post, it is necessary to establish a protocol enabling long-term durability of the restorative treatment with glass fiber posts.

\section{METHODS}

This research had the project approved by the Research Ethics Committee in Human Beings of the Federal University of Juiz de Fora by Protocol 2001.060.2010.

The materials employed in this study are described in Table 1.

Table 1. Materials employed, composition, manufacturer, batch number, and expiration date

\begin{tabular}{|c|c|c|c|}
\hline Material & Composition & Manufacturer & Lot \\
\hline Panavia F 2.0 & $\begin{array}{l}\text { Binder A: silanized silica, colloidal silica, bisphenol A polietoxidimetacrilato, 10-metacriloiloxidecildihidro- } \\
\text { gênio phosphate, hydrophobic and hydrophilic dimethacrylate, camphorquinone and } \\
\text { benzoyl peroxide; } \\
\text { Binder B: silanized barium glass, silanized titanium oxide, sodium fluoride, colloidal silica, } \\
\text { polietoxidimetacrilato bisphenol A, dimethacrylate hydrophilic, hydrophobic dimethacrylate, } \\
\text { N-diethanol-p-toloudina sodium sulfinate 2,4,6-triisopropyl benzene. }\end{array}$ & $\begin{array}{l}\text { Kuraray Medical } \\
\text { Inc, Japan }\end{array}$ & $\begin{array}{l}\text { Pasta A } \\
00254 \text { A } \\
\text { Val: } 2013-03 \\
\text { Pasta B } \\
\text { 0031A } \\
\text { Val: } 2013-03\end{array}$ \\
\hline RelyX U100 & $\begin{array}{l}\text { Base Binder: glass fiber, AC esters. fosfóricometacrilato, TEGDMA, silica, silane, and sodium persulfate. } \\
\text { Catalyst Binder: glass fiber, replacement dimethacrylate, silica, silane, sodium ptoluenosulfonato and } \mathrm{Ca}(\mathrm{OH})^{2} \text {. }\end{array}$ & $\begin{array}{l}\text { 3M ESPE, St } \\
\text { Paul, MN, USA }\end{array}$ & $\begin{array}{l}440148 \\
\text { Val: } 2012-11\end{array}$ \\
\hline ED Primer A\&B & $\begin{array}{l}\text { ED Primer A: 2-hydroxyethyl methacrylate, 10-metacriloloxidecildihidrogênio phosphate, nmetacriloil } \\
\text { 5-aminosalicylic acid, N, N'-diethanol p-toluidine and water; } \\
\text { ED Primer B: N metacrioil5aminosalicílico, sulfinatobenzínico sodium, N, N'-diethanol p-toluidine and water. }\end{array}$ & $\begin{array}{l}\text { Kuraray Medical } \\
\text { Inc, Japan }\end{array}$ & $\begin{array}{l}\text { Primer A } \\
\text { 0301A } \\
\text { Primer B } \\
\text { 0176A }\end{array}$ \\
\hline $\begin{array}{l}\text { Pino de Fibra } \\
\text { de Vidro } \\
\text { Exacto Cônico }\end{array}$ & Fiberglass $80 \%$; epoxy resin $20 \%$ by weight. & $\begin{array}{l}\text { Ângelus, } \\
\text { Londrina, PR, } \\
\text { Brazil }\end{array}$ & $\begin{array}{l}\text { Lote: } \\
15902\end{array}$ \\
\hline Endofill & $\begin{array}{l}\text { Powder: zinc peroxide PA, hydrogenated rosin, bismuth subcarbonate, barium sulfate, anhydrous sodium borate. } \\
\text { Liquid: Eugenol }\end{array}$ & $\begin{array}{l}\text { Dentsply Ind } \\
\text { Comércio Ltda } \\
\text { do Brazil }\end{array}$ & $\begin{array}{l}\text { Lote } \\
662872 \mathrm{E}\end{array}$ \\
\hline Sealer 26 & $\begin{array}{l}\text { Powder: bismuth trioxide, calcium hydroxide, Hexamethylene tetramine, Titanium Dioxide. } \\
\text { Resin: Epoxy Bisphenol. }\end{array}$ & $\begin{array}{l}\text { Maillefer/ } \\
\text { Dentsply, USA }\end{array}$ & $\begin{array}{l}\text { Lote: } \\
\text { 587450D }\end{array}$ \\
\hline
\end{tabular}


Forty single-rooted human teeth with straight roots with $12 \mathrm{~mm}$ in length were selected after extraction due to periodontal reasons. The teeth were obtained in the Tooth Bank of the School of Dentistry of Juiz de Fora - Federal University of Juiz de Fora. The teeth were cleaned with the aid of an ultrasound device (PROFI II, Dabi Atlante, Brazil) and pumice (ASFER, Brazil) with water. Next they were stored into $0.5 \%$ chloramine (Vetec, Brazil) under refrigeration at $\pm 4^{\circ} \mathrm{C}$.

All endodontic treatments were performed by a single operator previously trained and calibrated. All teeth were submitted to step-back technique up to size 45 file (International Standardization Organization - ISO) at apical constriction, with working length set at $1 \mathrm{~mm}$ shorter of the apex, with the aid of stainless steel instruments (K-files Maillefer/Dentsply, New York, USA). Root canal was irrigated with $2.5 \%$ sodium hypochlorite $(\mathrm{NaOCl})$ (ASFER, Brazil) and 17\% ethylenediamine tetraacetic acid (EDTA) (Biodinâmica, Brazil) interchangeably. After instrumentation, the canals were irrigated with distilled water and dried with size 40 absorbent paper points (Tanari, Tamariman Industrial Ltda, Brazil). Obturation was executed with gutta-percha points (Dentsply, New York, USA) through lateral condensation technique. The following endodontic cements were used: calcium hydroxide (Sealer 26 - Maillefer/Dentsply, New York, USA) and zinc oxide and eugenol (Endofill-Dentsply). Root canal opening was closed with conventional glass ionomer cement (KetacTM Cem-3M, ESPE, USA), to avoid contamination. After that, the roots were stored into distilled water at $37^{\circ} \mathrm{C}$ until the endodontic filling removal and luting of glass fiber posts [9].

A size 3 largo drill (Microdont, Brazil) with $1.5 \mathrm{~mm}$ in diameter, $9 \mathrm{~mm}$ in length was used to remove the endodontic filling leaving $3 \mathrm{~mm}$ of material for apical sealing. Following, the teeth were cleaned with deionized water (ASFER, Brazil), and gently dried with size 40 absorbent points (Tamariman Industrial Ltda, Brazil), thus avoiding the complete drying after this step. The surfaces of glass fibers posts were treated with $24 \%$ hydrogen peroxide (Idem - compounding pharmacy, Brazil) for 10 minutes. Then, the silane agent (Silano, Ângelus Brazil) was applied on all post's surface for 1 minute. Next, the posts were gently dried for 15 seconds.

After the preparation of the teeth, the roots were randomly divided into four groups listed in Table 2.

Tabela 2. Distribuição dos grupos do estudo.

\begin{tabular}{cccc}
\hline Group & $\begin{array}{c}\text { Resinous } \\
\text { cement }\end{array}$ & Adhesive & $\begin{array}{c}\text { Cement } \\
\text { Shutter }\end{array}$ \\
$\mathrm{R}+\mathrm{E}$ & RelyX U100 & - & EndoFill \\
$\mathrm{P}+\mathrm{E}$ & PanaviaF2.0 & Primer A\&B & EndoFill \\
$\mathrm{R}+\mathrm{S}$ & RelyX U100 & - & Sealer 26 \\
$\mathrm{P}+\mathrm{S}$ & PanaviaF2.0 & ED Primer A\&B & Sealer 26 \\
\hline
\end{tabular}

R+E Relyx U100 + Endofill, P+E Panavia F2.0 + Endofill, R+S Relyx U100 + Sealer 26 $\mathrm{P}+\mathrm{S}$ Panavia F2.0 + Sealer 26
After the removal of the endodontic filling material, cleaning with deionized water (ASFER, São Paulo, Brazil), acid etching with 37\% phosphoric acid (Vigodent, Rio de Janeiro, Brazil) for 20 seconds, the canals were washed with deionized water (ASFER, Brazil) and dried with size 40 absorbent paper points (Tamariman Industrial Ltda, Manaus, Brazil). Next the luting protocol was carried out according to the cement used. In groups $\mathrm{P}+\mathrm{E}$ and $\mathrm{P}+\mathrm{S}$, a resin cement was employed (Panavia F - Kuraray-Japan). Equal proportions of ED Primer A and B were mixed and then applied into intraradicular dentin for 20 s with medium compression movements against the root canal walls. Next, the excess of the solution was removed with size 40 absorbent paper points (Tamariman Industrial Ltda, Brazil). Equal proportions of pastes $\mathrm{A}$ and $\mathrm{B}$ of the resin cement were dispensed onto a paper block and hand mixed for 20 seconds, with the aid of a plastic spatula (SSWhite, Rio de Janeiro, Brazil). The resin cement was introduced within root canal with the aid of a Centrix syringe (DFL, Rio de Janeiro, Brazil). Then, the glass fiber post was inserted with the aid of dental tweezers (SSWhite, Rio de Janeiro, Brazil). The cement excess was removed with the aid of a disposable applicator (Microbrush - KG Sorensen, Rio de Janeiro, Brazil) and light-cured for 60 seconds with the aid of a light-curing unit (Dabi Atlante Eletronic - Dabi Atlante, Ribeirão Preto, Brazil) with a light intensity of $700 \mathrm{mw} / \mathrm{cm}^{2}$ placed coronal-apically with its tip centered in the glass fiber post.

In groups R+E and R+S, RelyX U100 (3M ESPE, EUA) was used. The cement was dispensed onto a paper block and mixed for 20 seconds with the aid of a plastic spatula (SSWhite, Rio de Janeiro, Brazil) The cement was inserted into root canal with the aid of a Centrix syringe (DFL, Rio de Janeiro, Brazil). Then, the glass fiber post was inserted with the aid of dental tweezers (SSWhite, Rio de Janeiro, Brazil). The cement excess was removed with the aid of a disposable applicator (Microbrush - KG Sorensen, Rio de Janeiro, Brazil) and light-cured for 60 seconds with the aid of a light-curing unit (Dabi Atlante Eletronic - Dabi Atlante, Ribeirão Preto, Brazil) with a light intensity of $700 \mathrm{mw} / \mathrm{cm}^{2}$ placed coronal-apically with its tip centered in the glass fiber post.

The samples were subjected to thermocycling in a thermocycling machine (MSCT-3 Plus - Erios, São Paulo, Brazil) at 6,000 cycles for 30 seconds each $\left(5 \pm 1^{\circ} \mathrm{C}\right.$ and $\left.55 \pm 1^{\circ} \mathrm{C}\right)$.

The samples were then fixed into an acrylic resin (Jet, São Paulo, Brazil) base with the aid of dental delineator (Bioart, São Carlos Brazil), and the crowns were removed with the aid of size 3100 drill (KG Sorensen, Rio de Janeiro, Brazil) at high speed under constant refrigeration. Following, the roots were sectioned perpendicularly to the posts into cuts of $2 \mathrm{~mm}$ in thickness with the aid of a cutting machine (Isomet 1000 Precision Saw - South Bay Technology Inc., Buehler, Lake Bluff, USA) and a diamond disc (EXTEC 12258, EUA) under constant refrigeration.

To be submitted to push-out test, each root was divided into four cuts according to the area: apical, medium apical, medium coronal and coronal. 
The samples were individually positioned onto a stainless steel holder containing a central perforation with $2 \mathrm{~mm}$ in diameter. Because of the conical shape of the posts, the load was applied at apical-coronal direction, so that the post was pushed towards the largest portion of the canal. The load was applied only on the post surface, without applying on the cement and/or dentin, through a cylindrical tip of $0.8 \mathrm{~mm}$ in diameter, coupled to an universal testing machine (EMIC, São José dos Pinhais, Brazil), with load cell of $50 \mathrm{~N}$, at crosshead speed of $0.5 \mathrm{~mm} / \mathrm{min}$.

The displacement force of the post was recorded at the moment in which the post detached from the canal.

The following formula was applied: $(\alpha)=\mathrm{F} / \mathrm{A}$, where $\mathrm{F}$ is the force in $\mathrm{MPa}$ at the moment that the fiber glass post detached from the root canal.

Because of the cylindrical shape of the posts, the diameter and the cuts underwent little variation, so that the samples were measured with the aid of a digital caliper to assure data reliability and the area in $\mathrm{mm}^{2}$ was obtained using the formula below:

$$
\begin{aligned}
& \qquad \mathrm{A}=\pi(\mathrm{R} 1+\mathrm{R} 2)\left[\mathrm{h}^{2}+(\mathrm{R} 2-\mathrm{R} 1)^{2}\right]^{0.5} \\
& \pi=3.14 \\
& \mathrm{R} 2=\text { coronal radius of the post fragment } \\
& \mathrm{R} 1=\text { apical radius of the post fragment } \\
& \mathrm{H}=\text { cut thickness. }
\end{aligned}
$$

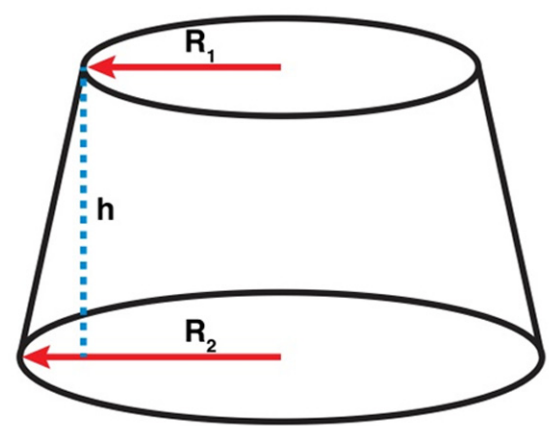

To evaluate the effect of the endodontic cement (EndoFill or Sealer 26) and resin cement (RelyxU100 or Panavia F2.0), three-way ANOVA (endodontic cement, resin cement, area evaluated) was applied followed by Tukey test.

The results passed both the normality test (KolmogorovSmirnov) and test for equality of variances (Levene test). All tests were two-tailed and the level of significance was set at $5 \%$.

The statistical analyses were executed with the aid of software (Statistical Package for Social Sciences - SPSS), version 13.0 for Windows (Chicago, IL, USA) and Graphpad Prism version 5.0 for Windows (La Jolla, CA, USA).

\section{RESULTS}

All distribution followed the normality curve.

Three-way ANOVA showed that the endodontic cement, resin cement, and area evaluated were significant factors; however, there were no interactions among these parameters (cement 1: $\mathrm{F}_{1,144}=125.10, \mathrm{p}<0.001$; cement $2>\mathrm{F}_{1,144}=25.97$, $\mathrm{p}<0.001$ and area: $\left.\mathrm{F}_{3,144}=73.49, \mathrm{p}<0.001\right)$.

The use of Sealer 26 exhibited mean bond strength values higher than those of EndoFill $(\mathrm{p}<0.001)$.

Panavia F 2.0 showed mean bond strength values higher than those of RelyX U100 ( $<<0.001)$.

The apical and medium apical areas presented mean bond strength values smaller than those of medium coronal $(p<0.001)$ and coronal $(p<0.001)$ areas.

The coronal area exhibited the highest mean bond strength values among all regions evaluated $(p<0.001)$.

\section{DISCUSSION}

The choice for glass fiber posts (GFP) associated with adhesive restorative materials has been an alternative largely used for the restoration of teeth endodontically treated because it can be a clinical option rather than metallic post and core [12].

Many studies have been conducted on the bonding of resin luting agents to root dentin since most of the failures occur in the adhesive interface between the luting agent and dentin. These studies have demonstrated satisfactory performances when teeth endodontically treated and restored with GFP were analyzed $[1,13,14]$. The most current studies have been proposed to verify a higher effectiveness in adhesivity aiming to contribute to long-term durability of the restorations.

Similarly, other studies have researched the possible causes of the clinical failures related to the detachment of glass fiber posts and associated these failures with problems in the adhesive interface between the luting agent/root dentin mainly over time $[5,15,16,17]$.

The use of thermocycling enabled through the laboratorial aging of the samples to assess the durability of bonding of resin luting agent to root dentin. The temperature used in this study during the cycles of immersion was of $5 \pm 1{ }^{\circ} \mathrm{C}$ and $55 \pm 1^{\circ} \mathrm{C}$. The rationale behind this was based on the similarity with the temperature of the food ingested during the meals $[16,17]$.

This study evaluated the bond strength of glass fiber posts to root dentin, taking into consideration two variables: the type of endodontic filling material and resin luting agent employed in GFP luting procedure.

To measure the bond strength of the materials to root dentin some methods have been studied: tensile, microtensile and push-out tests. In this study, push-out test was chosen because of its advantages when compared with microtensile test. Among them, the possibility of a small loss of the samples. Likewise, during microtensile tests through toothpick- or hourglass-shaped specimens, premature failures have been common during the preparation and cutting of the specimens resulting in higher standard deviation values $[5,18]$.

The null hypothesis of this study was that it would not be statistically significant differences in the bond strength 
values of the luting agents tested, which was rejected. This corroborates the findings of Ferrari et al. (2000) [13], Monticelli et al. (2005) [1], Tuncdemir et al. (2012) [14], which also observed similar results.

Consequently the hypotheses that (1) Panavia F 2.0 and Relyx U100 would influence on the durability of the bonding of the glass fiber post to intraradicular dentin; and (2) the endodontic cement (Endofill) would influence on the bond strength of glass fiber posts were confirmed. These results evidenced the effect of eugenol on the chemical polymerization of resin luting agents.

Other factor that could have influence on these results is the greater viscosity of Relyx U100. These findings were in agreement with those of the studies of Dias et al. (2009) [8], Ebert et al. (2011) [19], da Silveira et al. (2011) [9], Mazzitelli et al. (2012) [17], Tuncdemir et al. (2012) [14], in which it was verified a greater bond strength when glass fiber posts were luted with resin cements by using acid etching with $37 \%$ phosphoric acid followed by the application of conventional adhesive systems. The observations of the study of Goracci et al. (2004) [18] suggested that these differences could be partially attributed to the ability of either dentin adhesives or self-cured resin luting agents to infiltrate within dentin through the smear layer.

The use of $37 \%$ phosphoric acid prior to the application of the primer and bonding agents provides the removal of both smear layer on root dentin and smear plugs present on the openings of the dentinal tubules enabling an effective micromechanical retention of the resin luting agent $[2,19]$.
During the luting of glass fiber posts, the bond strength of the luting agent to the dentinal walls is affected by the distribution of the cement along with the cervical, medium and apical thirds. Accordingly, the morphological and histological features of the root canal, including the orientation of the dentinal tubules, may affect the quality of the luting procedure [13].

The different areas of the root canal show many distributions and densities inside the dentinal tubules. These densities significantly decrease from cervical to apical third of the root canal. In this study, there was no statistically significant differences between the medium apical and apical areas (Table 3), which could be justified by the action of the eugenol on the chemical polymerization of the luting agents tested $[2,13,19]$.

The results obtained in this study were expected because: (1) there exist a higher difficult in accessing the medium apical and apical region thorugh photopolymerization; (2) the possible flowing limitations of the luting agent; (3) the influence of eugenol on the chemical curing of the resin luting agent; (4) gutta-percha remnants after mechanical preparation; (5) acid etching of the root canal; and (6) presence of smear layer can influence negatively on the bond strength of the resin cement to root dentin.

Based on the results of this study, it was possible to clarify the interaction among the components of resin luting agents and endodontic cements in order to establish a clinical protocol that result in long-term durability of the restorations.

Table 3. Mean and standard-deviation according to the area evaluated

\begin{tabular}{|c|c|c|c|c|c|}
\hline Group & Area evaluated & Cement 1 & Cement 2 & Mean (MPa) & $\begin{array}{c}\text { Standard-deviation } \\
\text { (MPa) }\end{array}$ \\
\hline $\mathrm{RE}$ & \multirow{4}{*}{ Apical } & EndoFill & RelyxU 100 & $1.35^{\mathrm{a}}$ & 1.28 \\
\hline PE & & EndoFill & Panavia F2.0 & $2.70^{\mathrm{b}}$ & 0.89 \\
\hline RS & & Sealer 26 & RelyxU 100 & $3.89^{\circ}$ & 0.70 \\
\hline PS & & Sealer 26 & Panavia F2.0 & $4.30^{\mathrm{C}}$ & 1.02 \\
\hline $\mathrm{RE}$ & \multirow{4}{*}{ Medium apical } & EndoFill & RelyxU 100 & $1.38^{\mathrm{a}}$ & 1.28 \\
\hline PE & & EndoFill & Panavia F2.0 & $2.98^{b}$ & 1.43 \\
\hline RS & & Sealer 26 & RelyxU 100 & $4.02^{\mathrm{c}}$ & 1.14 \\
\hline PS & & Sealer 26 & Panavia F2.0 & $4.49^{c}$ & 1.82 \\
\hline $\mathrm{RE}$ & \multirow{4}{*}{ Medium coronal } & EndoFill & RelyxU 100 & $2.46^{a}$ & 0.73 \\
\hline $\mathrm{PE}$ & & EndoFill & Panavia F2.0 & $3.72^{\mathrm{b}}$ & 0.78 \\
\hline RS & & Sealer 26 & RelyxU 100 & $4.85^{\circ}$ & 0.71 \\
\hline PS & & Sealer 26 & Panavia F2.0 & $6.14^{\mathrm{d}}$ & 0.73 \\
\hline RE & \multirow{4}{*}{ Coronal } & EndoFill & RelyxU 100 & $5.59^{b}$ & 1.08 \\
\hline PE & & EndoFill & Panavia F2.0 & $5.74^{\mathrm{b}}$ & 1.06 \\
\hline RS & & Sealer 26 & RelyxU 100 & $7.40^{\mathrm{a}}$ & 1.51 \\
\hline PS & & Sealer 26 & Panavia F2.0 & $5.59^{b}$ & 1.08 \\
\hline
\end{tabular}

R+E Relyx U100 + Endofill, P+E Panavia F2.0 + Endofill, R+S Relyx U100 + Sealer 26, P+S Panavia F2.0+Sealer 26. 


\section{CONCLUSION}

Based on the results of this study, it can be concluded that: There was a relationship between the luting protocol of the glass fiber post and the endodontic cement and eugenol plays and important role inside the dentinal tubules by negatively interfering on the durability of the bond strength of the materials tested.

\section{REFERENCES}

1. Monticelli F, Osorio R, Albaladejo A, Aguilera FS, Ferrari M, Tay FR Toledano M. Effects of adhesive systems and luting agents on bonding of fiber posts to root canal dentin. J Biomed Mater Res B Appl Biomater 2005; 77(1):195-200. https://doi.org/10.1002/jbm.b.30420

2. Reis KR, Spyrides GM, Oliveira JA, Jnoub AA, Dias KRHC, Bonfante G. Effect of cement type and water storage time on the push-out bond strength of a glass fiber post. Braz. Dent. J. 2011;22(5):359-64.

3. Silva RN, Castro GC, Santos Filho CFP, Silva RG, Campos ER, Soares VP, Soares, JC. Influence of different post design and composition on stress distribution in maxillary central incisor: Finite element analysis. Indian J Dent Res. 2009;20(2):153-8. https://doi.org/10.4103/0970-9290. 52888

4. Radovic I, Mazzitelli C, Chieffi N, Ferrari M. Evaluation of the adhesion of fiber posts cemented using different adhesive approaches. Eur J Oral Sci. 2008:116 (6):557-63. https://doi.org/10.1111/j.1600-0722.2008.00577.x

5. Silva LM, Andrade AM, Machuca FMG, Silva PMB, Silva RVC, Veronezi MC. Influence of different adhesive systems on the pull-out bond strength of glass fiber posts. J Appl Oral Sci. 2008;16(3):232-5. https://doi. org/10.1590/S1678-77572008000300013

6. Santini MF, Rippe MP, Franciscatto GJ, Rosa RA, Valandro LF, Só MVR, et al. Canal Preparation and Filling Techniques do not Influence the Fracture Resistance of Extensively Damaged Teeth. Braz. Dent. J. 2014;25(2): 129-35. https://doi.org/10.1590/0103-6440201

7. da Silva MB, Tavarez RR, de Assis FS, Tonetto MR, Neto TP, Bhandi SH, El-Mowafy O, Porto Neto Sde T, Bandeca MC. The Effect of Self-adhesive and Self-etching Resin Cements on the Bond Strength of Nonmetallic Posts in Different Root Thirds. J Contemp Dent Pract. 2015;16(2):147-53. https://doi.org/10.5005/jp-journals-10024-1652

8. Dias LLL, Giovani AR, Silva Sousa YTC, Luiz Vansan P, Alfredo E, SousaNeto MD, Paulino SM. Effect of eugenol-based endodontic sealer on the adhesion of intraradicular posts cemented after different periods. J Appl Oral Sci. 2009:17(6):579-83. https://doi.org/10.1590/S167877572009000600008
9. da Silveira OC, da Silva RB, Dametto FR, Machado CT, dos Santos AJS Cavalcanti AL. Efeito do tipo de cimento na resistência à extrusão de pino de fibra de vidro. Revista Eletrônica de Materiais e Processos. 2011 6(1):28-34.

10. Carvalho CN, Bauer J, Ferrari PH, Souza SF, Soares SP, Loguercio AD, Bombana AC. Influence of calcium hydroxide intracanal medication on bond strength of two endodontic resin-based sealers assessed by micropush-out test. Dent Traumatol. 2013 Feb;29(1):73-6. https://doi. org/10.1111/j.1600-9657.2011.01109.x

11. Hasegawa EA, Boyer DB, Chan DC. Hardening of dual-cured cements under composite resin inlays. J Prosthet Dent. 1991; 66(2):187-92. https:// doi.org/10.1016/S0022-3913(05)80046-0

12. Schwartz RS, Robbins JW. Post placement and restoration of endodontically treated teeth: a literature review. J Endod. 2004 May 30(5):289-301. https://doi.org/10.1097/00004770-200405000-00001

13. Ferrari M, Vichi A, Grandini S, Goracci C. Efficacy of a self-curing adhesiveresin cement system on luting glass-fiber posts into root canals: an SEM investigation. Int J Prosthodont. 2001 Nov-Dec;14(6):543-9.

14. Tuncdemir AR, Yildirim C, Güller F, Ozcan E, Usumez A. The effect of postsurface treatments on the bond strength of fiber posts to root surfaces. Lasers Med Sci. 2013 Jan;28(1):3-8. https://doi.org/10.1007/ s10103-012-1053-z

15. Sadek FT, Goracci C, Monticelli F, Grandini S, Cury AH, Tay F, Ferrari M. Immediate and 24-Hour Evaluation of the Interfacial Strengths of Fiber Posts. J Endod. 2006;32:1174-7. https://doi.org/10.1016/j. joen.2006.07.005

16. Feitosa VP, Medina ADC, Puppin-Rontani RM, Correr-Sobrinho L, Sinhoreti MAC. Effect of Resin Coat Technique on Bond Strength of Indirect Restorations after Thermal and Load Cycling. Bull Tokyo Dent Coll. 2010; 51(3):111-8. https://doi.org/10.2209/tdcpublication.51.111

17. Mazzitelli C, Monticelli F, Toledano M, Ferrari M, Osorio R. Effect of terma cycling on the bond strength of self-adhesive cements to fiber posts. Clin Oral Investig. 2012 Jun;16(3):909-15. https://doi.org/10.1007/s00784-011. 0576-1

18. Goracci C, Tavares AU, Fabianelli A, Monticelli F, Raffaelli O, Cardoso PC, Tay F, Ferrari M. The adhesion between fiber posts and root canal walls: comparison between microtensile and push-out bond strength measurements. Eur J Oral Sci. 2004 Aug:112(4):353-61. https://doi. org/10.1111/j.1600-0722.2004.00146.x

19. Ebert J, Leyer A, Gunther O, Lohbauer U, Petschelt A, Frankenberger $\mathrm{R}$, Roggendorf MJ. Bond Strength of Adhesive Cements to Root Canal Dentin Tested with a Novel Pull-out Approach. J Endod. 2011;37 1558-61. https://doi.org/10.1016/j.joen.2011.08.009 